San Antonio Review • San Antonio Review (Volume V | Summer 2021)

\title{
Echoes of Injustice
}

\author{
William 0. Pate II
}

${ }^{1}$ San Antonio Review

Published on: Sep 12, 2021

DOI: $10.21428 / 9 b 43 c d 98 . e a d 8 a 68 b$

License: Creative Commons Attribution 4.0 International License (CC-BY 4.0). 


\section{Reverberations of Racial Violence: Critical \\ Reflections on the History of the Border \\ Edited by Sonia Hernández and John Morán \\ González \\ UT Press, 2021 \\ 9781477322680 \\ 328 pages}

\section{REVERBERATIONS}

OF RAGIAL VIOLENGE

GRITIGAL REFLECTIONS

ON THE HISTORY OF

THE BORDER

Eatited by Sonia Hernandez and John Moran Gonzzalez

re-back

specere look at

spectare to see/to look

respect to see again

Its original Latin root, spectare, means "to see" or "to look." To respect is, in some ways, "to see again," or to look back and see each other with fresh eyes. $\underline{1}$

In the summer of 1975, doctoral student James A. Sandos happened upon carbon copies of the first two volumes of the three-volume 1919 report, "An Investigation of the Texas Ranger Force" $\underline{2}$ while conducting research at the U.S. National Archives in Maryland. $\underline{3}$ The report was one result of a legislative inquiry led by Texas state Rep. Jose T. Canales, the state's sole Mexican American legislator at the time, into the violence perpetrated by Texas Rangers along the U.S.-Mexico border in the state between 1910 and 1920. Later that summer, Sandos traveled to the Texas State Archives in Austin to review the original report - including the missing third volume. He discovered it had been sealed from public eyes by the Legislature for 50 years upon publication, an embargo that had expired six years before in 1969. $\underline{4}$ The only person noted as having looked at the report between 1919 and 1975 was well-known historian Walter Prescott Webb in the 1930s while researching his hagiography, The Texas Rangers: A Century of Frontier Defense. It was then Sandos understood why the third volume hadn't been copied and sent to Washington, D.C.: 
The first two volumes documented raids, primarily from Mexico, on American citizens who were living and working in South Texas, across the river that served as a boundary called Rio Bravo by Mexicans and Rio Grande by Americans. The third volume had not been sent to the National Archives, I suspect, because it dealt mainly with Texas Ranger atrocities against Mexicans and Mexican Americans. $\underline{5}$

Since 2013, the Refusing to Forget project has pushed for the public acknowledgment of a largely forgotten era of illegal yet tacitly state-sanctioned killings of Mexican Americans living along the border of the U.S. and Mexico border during the first quarter of the 20th century. 6 In less than a decade, the multidisciplinary group of scholars has worked to raise awareness of La Matanza, or "The Massacre," through applying and advocating for historical markers, $\underline{7}$ sparking the organization of a groundbreaking and award-winning exhibit at the Bob Bullock Texas State History Museum in Austin in early 2016 $\underline{8}$ and a National Endowment for the Humanitiessponsored Conference on the Centennial of the 1919 Canales Investigation of the Texas Rangers in 2019. $\underline{9}$ The group's latest effort at collective anamnesis, $\underline{10}$ a result of the 2019 conference, is the University of Texas Press collection, Reverberations of Racial Violence: Critical Reflections on the History of the Border. $\underline{11}$ The book presents the work of members of the project alongside contributions from others who became involved over the course of its existence, including the current director of the Bullock Texas State History Museum and descendants of those directly impacted by the violence.

U.S. Rep. Louie Gohmert and other Republicans' recent denials about and official rejection of the creation of a commission to investigate what has gone from being called "the insurrection" to "a riot" at the U.S. Capitol on January $6^{\text {th }}$ provides an interesting juxtaposition to the Texas House's investigation into the State Ranger Force a century ago.

While not necessarily a felt experience for Texas legislative leaders of the time, I think shame had to be among the motivations for hiding the third volume of the committee report from the federal government and wider public. But the shame and embarrassment that may have resulted from a real reckoning were instead prevented from ever occurring.

Arguments that (structures) "things are different now" and people have changed begin to ring hollow when we see Republican elected leaders attempt to erase the White 
Christian nationalist violence that happened only months ago without even supporting a search for its causes. $\underline{12}$

Texas Republicans' efforts to ban discussions of racism in Texas classrooms are a similar effort. As Reverberations on Racial Violence is subtitled Critical Reflections on the History of the Border, I'm going to emphasize "critical." $\underline{13}$

Much of the right's argument with critical race theory, if we take their arguments on their face, is that it imputes inherent racism to individuals, which I've not found to be true. This can be clearly seen in the inclusion of "hard work" and "meritocracy" as concepts exempt from questioning in Texas classrooms in House Bill 3979 (87R). The bill, which Gov. Abbott simultaneously signed and indicated did too little to move the needle on ensuring a Christian nationalist indoctrination of Texas students, outlaws the teaching of the following concepts in Texas public schools:

1. one race or sex is inherently superior to another race or sex;

2. an individual, by virtue of the individual's race or sex, is inherently racist, sexist, or oppressive, whether consciously or unconsciously

3. an individual should be discriminated against or receive adverse treatment solely or partly because of the individual's race or sex;

4. an individual's moral character, standing, or worth is necessarily determined by the individual's race or sex;

5. an individual, by virtue of the individual's race or sex, bears responsibility for actions committed in the past by other members of the same race or sex;

6. an individual should feel discomfort, guilt, anguish, or any other form of psychological distress on account of the individual's race or sex;

7. meritocracy or traits such as a hard work ethic are racist or sexist or were created by members of a particular race to oppress members of another race;

8. the advent of slavery in the territory that is now the United States constituted the true founding of the United States; or

9. with respect to their relationship to American values, slavery and racism are anything other than deviations from, betrayals of, or failures to live up to the authentic founding principles of the United States, which include liberty and equality; and

10. the 1619 Project.

Skipping the Republicans' enshrining a slight toward The New York Times in the Education Code, it's probably noteworthy that ensuring the positive light on "meritocracy" and "hard work" are included across the various bills filed to ban the 
teaching of accurate U.S. and Texas history courses throughout this year's regular and special legislative sessions. It may also be notable to some - certainly not Texas Republican legislators - that to teach the history of the concept of "meritocracy," one would have to inform students:

Michael Young coined the term 'meritocracy' in a satirical tale called The Rise of Meritocracy 1870-2033. This satire was intended to inspire reflection upon the folly of meritocratic life. $\underline{14}$

Granted, learning that would require a politician or staffer to perform a Google search and I hesitate to insist on such difficult background research, but it isn't unexpected these are the people who accidentally decriminalized cannabis across the state in the

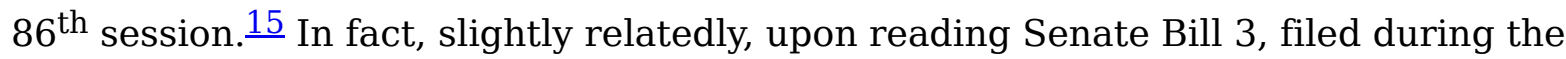
just-ended special session to finish the job poorly done by HB 3979 (remember: it included all those positive things the Democrats successfully amended onto it that Gov. Abbott couldn't abide), included its own ill-thought-out section reading:

a school district, open-enrollment charter school, or teacher may not require, make part of a course, or award a grade or course credit, including extra credit, for a student's:

(A) work for, affiliation with, or service learning in association with any organization engaged in:

(i) lobbying for legislation at the federal, state, or local level; or

(ii) social policy advocacy or public policy advocacy;

(B) political activism, lobbying, or efforts to persuade members of the legislative or executive branch at the federal, state, or local level to take specific actions by direct communication; or

(C) participation in any internship, practicum, or similar activity involving social policy advocacy or public policy advocacy; $\underline{16}$

I do wonder about the effects on internships at corporations engaging in lobbying activities, though, should such language ever become law. Indeed, some school districts are already interpreting existing legislation this way:

In College Station, some government teachers won't be asking students to take notes at city public meetings for a grade. Elementary school students in Leander won't be asking students to write letters addressing lawmakers anymore. In 
Keller, some resources offered online to students, including ebooks and news articles have been temporarily removed.

Officials at a school district about 30 miles north of Dallas decided to stop offering course credit to middle school students participating in a renowned nationwide civil engagement program "out of an abundance of caution." $\underline{17}$

\section{I digress.}

If there are concepts the right is worried about being taught because they might undermine support for their policies, it's more basic ones like "human" and "not human" or "rational" and "not rational" or "autonomous" and "dependent" and "interdependent" they should fear. "Meritocracy" and "hard work" are based on more fundamental understandings of what is considered normal and rational behavior historically, defined by a White male default $\underline{18}$ - and, thus, human. Those categorized as inhuman (a category that, for most of human history, included women, Black and Brown and Indigenous people and often seems to still include unassimilated foreigners and immigrants and, of course, all not-human beings) had no inherent merit nor were they considered to have property rights to whatever merit they may have been incidentally afforded. In fact, it may be just that binary/dualistic/dichotomous thinking we need to work at transcending -- in our classrooms and our daily lives. If I were to go further, I might suggest a more ecological and relational pedagogy and worldview. $\underline{19}$

But their refusal to admit to even the possibility of "structural racism" that might mold and determine, to some degree, the attitudes and actions of individuals is tantamount to denying that any negative discrimination against non-White people possibly currently exists. $\underline{20}$ If people aren't inherently racist and the various structures and institutions that were set up (often during times of slavery and colonization) and still administer our lives to a large degree can't be racist, then, clearly, those who are racist can only be . . . what? Crazy? Mistaken? Stupid? And this goes as much for the White incel feeling dispossessed of his supposed privilege as it does for any other traditionally Othered individual. These are some of the illogical cognitive somersaults involved in modern-day White supremacy and right-wing thought. Unless, that is, you go back to the definition of fascism. Those on the right would like to pass off enduring racist structures as just the effects of people who don't like some other folks.

Those on the right would like to have us believe and accept that it's just individuals -

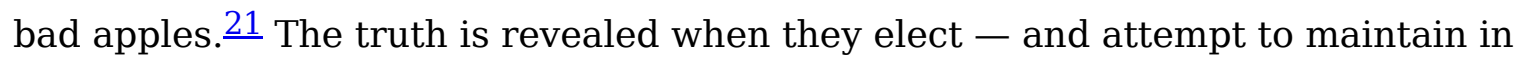
power through violence - rotten apples as world leaders. $\underline{22}$ 
In fact, I think most people wonder what value these people find in making themselves look like fools when they claim an event that clearly occurred didn't happen.

The answer is simple - if hardly believable because of its simplicity. History and common knowledge are written through repetition, erasure and dissimulation. If you say it enough, it becomes true. If you block out facts and overwrite them a million times with falsehoods, you can indeed fool a certain contingent. In fact, there are those, like fake historian David Barton, actively looking for well-crafted, believable lies (or disingenuous shadings of the truth, a favorite of National Review) they can peddle as justifications for their personal desires and profits. $\underline{23}$ If anything should be surprising, it might be the blatant lies forwarded by individuals so well-placed in the Republican elite.

I know it sounds stupid, but it's true. History isn't made by historians. History is made by those who leave a trace. Archives are filled with the materials individuals considered valuable enough to save and store and, ultimately, donate to a longerlasting institution. Reverberations includes reflections on the roles and responsibilities of museums to their communities. But the role of individuals, families and community groups in preserving memories for later retrieval and exposure is also highlighted. If the records don't exist, if the stories aren't passed down, if no one takes the time to make these sources accessible, critically important episodes from our histories can be lost forever.

It's the reason people - politicians, especially - write books: to leave their version of events with their justifications and their perspectives. Of course, most people don't write books. They're banking on that.

The vigorous concern shown for the continued memorialization of Confederate statues is another demonstration of this work. Keeping those statues in public places are seemingly innocuous reminders and reiterations of the status quo. They're subtle. Which is part of the reason for Refusing to Forget's work to install historical markers at the sites of significant state violence. It is not only an acknowledgment by the state and an educational site for those who happen to read it, it's that subtle reminder that the way things are isn't the result of false heroism but rather violence, dispossession and self-blindness. And the point of pointing that out is to make us remember that we choose whether to continue to operate in ways that produce those effects. That's what reverberations are: the echoes of past acts that still impact our present and limit our futures, if we let them and even more if we don't know about them. 
The point isn't to blame entire categories of living or dead people. There are many examples in the book of white individuals, like Kirby F. Warnock's grandfather, who did the right thing because they recognized the basic humanity of someone with darker

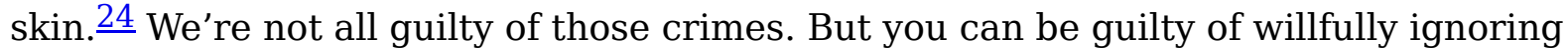
them or trying to erase them. That's called epistemic injustice - or even violence. $\underline{25}$ It's been said that denying such murders is akin to recommitting them - indeed, makes the actual commission of them again more likely. $\underline{26}$ Denying the validity of others' histories and experiences is among the "more ordinary and dingy complicities" in which we each partake that can lead to the "easy stupidity, the thoughtlessness, that [leads] to banal evil, even mass slaughter," as Hannah Arendt warned. $\underline{27}$

We have to refuse to forget in order to recognize that the acts we abhor in the past still continue today. The same violent dispossession and erasure along the U.S.-Mexico border helped along by the Texas Rangers and other state officials (to this day) continues to occur not only there but in the Occupied Territories of Palestine, the oil palm plantations in Indonesia, the narcostates and Indigenous lands of Colombia, the "green" energy landgrabs in Africa and elsewhere. $\underline{28}$

Who knows how long the 1919 Texas Ranger Investigation would have languished decaying and forgotten in the state archives had a graduate student not stumbled upon the (least interesting) parts of it in Washington, D.C.? Who knows how different history might have been were the truth more often told? In this case, we might, at a minimum, have prevented the ongoing Walker, Texas Ranger travesty. Certain Texas ranches might not encompass quite so many acres. It's that different history - and different future - that Texas Republicans and their allies really oppose. From 1919 to 2021, efforts to hide, erase, over-write, whitewash and otherwise falsify historical events that undermine their justifications for their positions remain the most effective way to maintain the status quo and ensure their continued dominance, control and profit. They don't care about the nation or history. They only care about themselves. And such self-satisfied narcissism is exactly what enables the devaluing of others to death. By refusing to acknowledge and recognize others' perspectives and sufferings, we increase the likelihood of not recognizing and, thus, resisting and stopping the repetition of past horrors.

That's why it's important we refuse to forget. One way to start is by reading this collection. 
William O. Pate II is the founding editor and publisher of San Antonio Review.

\section{Footnotes}

1. Bruinius, Harry. "Respect: Is it the glue a polarized nation needs?" The Christian Science Monitor, https://www.csmonitor.com, June 14, 2021, page 27.

2. I am in the process of creating a machine-readable transcription of the entire report beginning with Volume 3. An excerpt is provided in this issue. Find the rest at 1919 Texas Ranger Investigation. 1st ed., San Antonio Review, 2021. DOI.org (Crossref), https://doi.org/10.21428/9b43cd98.858b0f1d. The facsimile PDFs being used can be found on the Texas State Library and Archives Commission's site at https://www.tsl.texas.gov/sites/default/files/public/tslac/treasures/. Rangers and Outlaws / TSLAC. https://www.tsl.texas.gov/treasures/law/index.html. Accessed 12 Sept. 2021.

3. IJames A. Sandos "Recovering the 1919 Canales Investigation of the Texas Ranger Force: Archival Investigation and Its Consequences, 1975-2010,” in Hernández, Sonia, et al., editors. Reverberations of Racial Violence: Critical Reflections on the History of the Border. First edition, University of Texas Press, 2021.

4. 
Only after print publication did I run across this footnote in a very useful chronology of the Texas Ranger Investigation and history of the transcript by Richard Ribb, Ph.D.:

Secretary Pridemore produced three texts in all; see Pridemore to Harley, 10May19, AGGC. A second text exists in the Harbert Davenport Papers, Miscellaneous Papers, TSLA. According to James Sandos, the third copy is in the files of Mexican Claims Commission of 1923, Records of Boundary, Commissions, and Arbitrations, Record Group 76, U.S. National Archives, Washington, D.C. Sandos writes, "The committee ordered its own three volumes of testimony sealed," which is not the case; Rebellion in the Borderlands: Anarchism and the Plan of San Diego, 1904-1923 (Norman and London: U. of Oklahoma Press, 1992), 207. Canales's last legislative act was to place a copy of the transcript in the State Library, "to be kept as one of the archives of the state." Perhaps aware of the possibility that the copy might disappear, Canales included in his resolution the necessity for obtaining a receipt from the State Librarian; House Journal, 36th Leg., 1st \& 2nd Called Sess. (5May-22July19), July 15, 420. In 1975 Sandos was told that he was the first to see the copy in the Legislative Papers since Walter P. Webb in the 1930s; Rebellion, 210, n.11. Carlos Larralde reported that a University of Texas librarian had considerable difficulty in gaining access to the transcript. She informed Larralde that the "proceedings were lost for eight years" at one point; Martha P. Cotera to Larralde, 26Sept1979, cited in Larralde, “J. T. Canales and the Texas Rangers," Journal of South Texas 10 (Fall 1997), n.1, 58. My take is that Webb and the Ranger loyalists at the archives in his thrall informally made them off limits in the 1930s.

See Robert Ribb. “A Reader's Guide to the 'Proceedings of the Joint Committee of the Senate and the House in the Investigation of the Texas State Ranger Force' (1919)." San Antonio Review, Aug. 2020,

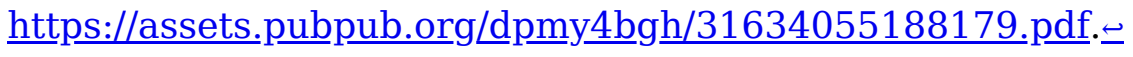

5. Ibid. $\triangleq$ 6.

Learn more about the Refusing to Forget project at their website at https://refusingtoforget.org/. Sam Houston State University maintains a useful map of over 600 lynchings in Texas between the years of 1882 and 1945. See https://lynchingintexas.org. 
7. “Historical Markers.” Refusing to Forget, 15 Feb. 2018, https://refusingtoforget.org/historical-markers/.. \pm

8. Life and Death on the Border 1910-1920 | Bullock Texas State History Museum. https://www.thestoryoftexas.com/visit/exhibits/life-and-death-on-the-border-19101920. Accessed 11 Sept. 2021.

9. Reverberations of Racial Violence - A Project Funded by the National Endowment for the Humanities. http://canalesconference.dh.tamu.edu/. Accessed 11 Sept. 2021. 10. Martinez, Monica Muñoz. The Injustice Never Leaves You: Anti-Mexican Violence in Texas. Harvard University Press, 2018, page $294 \boxminus$ 11. Hernández, Sonia, et al., editors. Reverberations of Racial Violence: Critical Reflections on the History of the Border. First edition, University of Texas Press, 2021.

12. Which is really little different from their non-response to the many other catastrophes the nation and world have faced in the past two years. $\bullet$ 13. While not a work of critical race theory specifically or disciplinarily, this is exactly the sort of work current Texas Republicans leaders are opposed to being discussed in Texas public school history and social studies classrooms. That it is a history book thus makes it all the more relevant to current debates. $\subseteq$ 14. Allen, Ansgar. "Michael Young's The Rise of the Meritocracy : A Philosophical Critique." British Journal of Educational Studies, vol. 59, no. 4, Dec. 2011, pp. 36782. DOI.org. (Crossref), https://doi.org/10.1080/00071005.2011.582852. 15. "How Texas Accidentally Decriminalized Cannabis." Cannabis Now, 5 Mar. 2020, https://cannabisnow.com/how-texas-accidentally-decriminalized-cannabis/. 16. For Senate Bill 3(87-1), visit https://capitol.texas.gov/BillLookup/Text.aspx? $\underline{\text { LegSess }=871 \& \text { Bill }=\text { SB3 }} \Leftarrow$

17. McKinney Ends Youth and Government Class Due to New Texas Social Studies Law | The Texas Tribune. https://www.texastribune.org/2021/08/17/texas-socialstudies-mckinney-youth-government/. Accessed 12 Sept. 2021. CNN, Nicole Chavez. "Confusion Reigns in Texas as New Law Aims to Restrict How Race and History Are Taught in Schools." CNN, https://www.cnn.com/2021/09/01/us/texas-critical-racetheory-social-studies-law/index.html. Accessed 12 Sept. 2021. 
18. As my longtime friend and $S A R$ prose editor, Ash Lange, said regarding a former collective member's desire for absolute freedom in the content he published under the $S A R$ banner, "Cock is not the default setting." $\subseteq$ 19. Along the lines discussed in Zúñiga, Didier. "Ecologizing Democratic Theory: Agency, Representation, Animacy." Contemporary Political Theory, Aug. 2021. DOI.org (Crossref), https://doi.org/10.1057/s41296-021-00514-9. 20. Chris Cameron. "In a Speech to a New Hampshire G.O.P. Group, Pence Calls Systemic Racism a 'Left-Wing Myth.'” The New York Times, 3 June 2021, https://www.nytimes.com/2021/06/03/us/politics/pence-trump-systemic-racism.html. Pope Francis offers another view in Evangelii Gaudium: "Changing structures without generating new convictions and attitudes will only ensure that those same structures will become, sooner or later, corrupt, oppressive and ineffectual." Evangelii Gaudium : Apostolic Exhortation on the Proclamation of the Gospel in Today's World (24 November 2013) / Francis.

https://www.vatican.va/content/francesco/en/apost_exhortations/documents/papafrancesco esortazione-ap_20131124 evangelii-gaudium.html. Accessed 8 Oct. 2021. 21. Bob Smietana. "Former Trump Official's God-and-Country Nonprofit Calls CRT a Threat to 'Colorblind Society.'” Religion News Service, 7 July 2021, https://religionnews.com/2021/07/07/god-and-country-nonprofit-run-by-former-trumpofficial-sees-critical-race-theory-as-threat-to-colorblind-society-russ-vought-islamracism/.

22. Belew, Kathleen. Bring the War Home: The White Power Movement and Paramilitary America. First paperback edition, Harvard University Press, 2019. Burley, Shane. Fascism Today: What It Is and How to End It. AK Press, 2017. 23. Author Amanda Ripley calls them "conflict entrepreneurs." See Humphries , Stephen. "Is Any Conflict Unsolvable? This Author Doesn't Think so." Christian Science Monitor, May 2021. https://www.csmonitor.com/USA/Society/2021/0519/Isany-conflict-unsolvable-This-author-doesn-t-think-so. Accessed 19 August 2021. Ripley, Amanda. High Conflict: Why We Get Trapped and How We Get Out. United States, Simon \& Schuster, 2021.

24. Blumenthal, Ralph. "New Charges Tarnish Texas Rangers' Image and Reopen Old Wounds." The New York Times, 31 Oct. 2004. NYTimes.com, 
https://www.nytimes.com/2004/10/31/us/new-charges-tarnish-texas-rangers-imageand-reopen-old-wounds.html. Accessed 12 Sept. 2021.

25. For more on epistemic injustice, see Fricker, M. (2003), "Epistemic Justice and a Role for Virtue in the Politics of Knowing." Metaphilosophy, 34: 154-

173. https://doi.org/10.1111/1467-9973.00266 $\leftrightharpoons$

26. For an excellent discussion of memory, forgetting and violence, see Hatcher, Rachel. The Power of Memory and Violence in Central America. Springer International Publishing, 2018. DOI.org. (Crossref), https://doi.org/10.1007/978-3-31989785-1. And I want to highlight this statement: "The battle for memory is not waged against forgetting, but against the different memories different social groups understand as truth."

27. Andrea Gadberry. "Night Thoughts: Am I Dizzy, Or Am I Dead?” The Philosopher, Autumn 2021, https://reader.exacteditions.com/issues/98097/spread/68. 28. For Indonesia, see Li, Tania, and Pujo Semedi. Plantation Life: Corporate Occupation in Indonesia's Oil Palm Zone. Duke University Press, 2021. 